UDC 811.111

DOI https://doi.org/10.32838/2710-4656/2021.4-2/21

Sheverun $\boldsymbol{N}$. $\boldsymbol{V}_{\text {. }}$
Kyiv National University of Trade and Economics

Lejzjus H. M.

National Transport University

Dzhurylo A. P.

National Transport University

\title{
BUSINESS STANDARDS IN THE VOCABULARY \\ OF INTERNATIONAL TREATIES AND FEATURES OF THEIR TRANSLATION
}

\begin{abstract}
The article is devoted to the investigation of business standards in the vocabulary of Englishlanguage international treaties and main features of their translation into the Ukrainian language. In the course of the research it was revealed that depending on the type of document, tasks of communicative nature the textual material of the document acquires one or another form of organization. This fact becomes crucial in the selection of language tools in the translation process. It is revealed that when translating treaties it is necessary to keep not only the semantic side, but also if possible to select structures that are closest or coincide with the structures in the original text both in terms of vocabulary and syntax, and in terms of grammatical constructions. In the process of investigation it was found out, that the syntactic and semantic structure of sentences of the treaties is very complex, dominated by complex syntactic units and verb forms. All this forces the translator to look for such a transformation that would correctly convey not only the grammatical content of the document, but also its pragmatic load. Analysis of special sources on the translation of international treaties has identified a number of factors that cause translation difficulties: a high degree of standardization of official business style and diplomatic background, differences in professional and sectoral pictures of the world and national-cultural specifics of terminological means of their verbalization, style and typological differences in lexical and grammatical means of the original and translated languages, norms of their use.
\end{abstract}

Key words: international treaty, international documentation, international communication, international cooperation, grammatical transformations.

Introduction. International treaty (contract) is materially executed agreement of two or more subjects of foreign economic activity and their foreign counterparties, aimed at establishing, changing or terminating their mutual rights and obligations in foreign economic activity [3, p. 18]. According to theRegulation "Ontheformofforeigneconomictreaties (contracts)", approved by the order of the Ministry of Economy of Ukraine from 06.09.2001 № 201 foreign economic treaty (contract) is concluded by the subject of foreign economic activity or its representative in simple written form, unless otherwise provided by international treaty or by law $[15$, p. 6]. Thus, the international treaty in the English-language business discourse fixes the moment of occurrence between the parties of certain rights and obligations and determines their scope. Currently, the language of foreign treaties is a very important indicator that determines the quality of any legal document. The text of any foreign treaty is usually overloaded with terms and terminological phrases, which are a certain "core" that connects different industries into one.

Today in international practice there are various types of international treaties, which in content and structure depend on the type of foreign transaction. For example, sales contracts, leasing, licensing, insurance, transportation and others among which the main ones are: with periodic delivery; one-time delivery; for the supply of complete equipment; with payment in cash, with payment in commodity or mixed form; "Turnkey"; on management; collective [17, p. 88].

Theoretical bacground. Various aspects of official business documents' translation have been in the center of attention of many scientists-translators 
(I. Borisenko [2], V. Kalyuzhna [5], V. Kyzym [7], V. Komissarova [10], G. Miram [13], L Yarova [18] and others). The analysis of special literature showed that in domestic linguistics the lexical features of English-language international documents translation were covered (O. Zaruma-Panskykh [4]); the specifics of discourse and terminology of English-language diplomatic documents are studied (N. Kashchyshyn [6]); the typology of international contracts and contracts documentation was studied (O. Konovchenko [11]). However, business standards in the vocabulary of international treaties and features of their translation remains insufficiently studied.

The purpose of this research is to consider the business standards and linguistic features of international treaties in English language and ways of their rendering into the Ukrainian language.

Results and discussion. The language of international treaties is the main tool that captures the will of the parties. According to the legislation of Ukraine, the foreign economic treaty of the subject of foreign economic activity of Ukraine with a foreign party must be concluded in Ukrainian and the language of the other party, that is in foreign language [1, p. 6-9]. Given that international treaties are concluded in the language of official business style, they must meet its basic characteristics, namely accuracy, brevity, clarity and conciseness. Usually, the process of signing an international treaty is preceded by a pre-contractual period during which preliminary negotiations are conducted. Since international treaties can be concluded in different foreign languages, communication between the parties takes place mainly in different languages, as a result of which the representatives of the parties may have a problem overcoming the language barrier. This problem, according to the researcher $\mathrm{V}$. Bigun can be solved through language mediation, that is the involvement of a specialist who speaks the languagesof the parties [1, p. 6-9]. Having considered the main forms of language mediation, we found out, that the leading place here is occupied by translation, which is carried out at different stages of the treaty concluding. Interpretation, which is carried out during the negotiations, and written translation, which takes place at the penultimate stage of work with the treaty. When translating international treaties in writing, the translator may have some difficulties with the translation of some of its provisions, and this is not surprising, because this type of translation has its own specifics.

When translating international treaties, special attention should be paid to:
1) the presence of false friends of the translator in the text of the treaty, which can lead to various inaccuracies and errors. For example: "The percentage ownership interests of the Parties are set forth below. - Розмір відсоткових часток участі Сторін зазначається нижче", а не “розмір власницького інтересу сторін»;

2) use of abbreviations and acronyms. The following types of abbreviations can be used in the texts of international treaties: textual (author's), which function within a certain text and have explanations; generally accepted, recorded in official directories and are part of the lexical system of the language. For example: $B / L$ - bill of lading - транспортна накладна, коносамент; C/O -certificate of origin свідоцтво про походження (товару, вантажу); L/C - Letter of Credit - акредитив and others;

3 ) the presence of words and phrases with implicit legal meaning in the texts of treaties. When translating implicit terms, it is necessary to restore the hidden seven and display them by adding the appropriate words. For example: defective delivery - поставка дефектного товару, а не недійсна ліиензія; orders and instruments - розпорядження й інші правові акти, а не накази й інструменти;

4) the presence of language stamps and clichés. The wording used in the English texts of international treaties has traditionally been a conservative way of creating legal documents, as evidenced by the presence in the texts of treaties of obsolete phrases and clichés such as: hereby (отже, таким чином); henceforth (надалі, віднині); with effect from the date hereof (починаючи із зазначеної дати); in witness whereof (свідчення чого); under and pursuant to this agreement (за цим договором) and others which have the appropriate equivalents in the Ukrainian language. Here are some examples of translation of language stamps and clichés in the texts of international treaties: "Continental Equipment Plc, Brighton, England, hereinafter referred to as "the Seller", on the one part, and TST Systems Ltd., Kyiv, Ukraine, hereinafter referred to as "the Buyer", on the other part..." - "Компанія Continental Equipment Plc, Брайтон, Англія, яка надалі іменується "Продавець", з однісї сторони, і компанія ТСТ Системз Лтд. Київ, Україна, яка надалі іменується "Покупещь", з іншої сторони".

Depending on the type of document, tasks of a communicative nature, the textual material of the document acquires one or another form of organization. This fact becomes crucial in the selection of language tools. Moreover, in different genres of documents language tools receive different 
semantic and logical-structural load. These tools are assigned a certain meaning and content in each type of document. Therefore, it should be borne in mind that when translating documents it is necessary to preserve not only the semantic side, but also, if possible, to select structures that are approximate or coincident with the structures in the original text both in terms of syntax and grammatical constructions.

As an example, we give the grammatical features of such international treaties as protocols translation - summary records of the speeches of delegates (participants), which reflect the results of negotiations between two parties [2, p. 75]. The form of communication of such document is written presentation of oral performance. Such provision affects the syntax and some grammatical features of the protocol language. Of particular note in the process of protocol's translation is the paragraph, used for a clearer demarcation of thought and syntactic parallelism. The use of the latter can be explained by the fact that the statement in the protocols is usually given in the form of indirect speech. In such case the main role is played by the verbs "speaking" or their contextual synonyms: to suggest, to express opinion, to stress, to support. The clarity of the protocol document is also facilitated by various conjunctions and connecting words, which create a logical sequence of presentation, especially when used at the beginning of the paragraph: then, moreover, nevertheless and others. Lexical means serve for logical merging and coherence of the text: as for smth - wo cmocycmbcя; with regard to smth відносно чого-небудь. The means of articulation also include ordinal numbers: first-no-nepme; secondly no-друге; thirdly-no-mpeme.

Grammatical constructions play an important role in creating a template. First of all, these are such constructions as obligatory inversion of the subject and predicate, adverbial inversion, passive form (often with the pronoun it as a subject), expression of the subject by the noun-by the subject of the passive construction.

Some researchers focus on adjective, infinitive and gerund inversions (V. Komissarov [9], G. Miram [13]). In particular, G. Miram believes that the translation of such inversions is directly related to their function in the sentence [14, p. 185].

The fact that the texts of the protocols also have a specific feature that affects both their composition and the choice of lexical means, emphasizes the scientist V. Kalyuzhna [5, p. 98]. Sentences in protocols can be logically connected not only by the so-called chain sequence, but also by more distant connections between sentences. At the same time, sentences can be combined at a large textual distance from each other within the framework of one speech, document, as well as go beyond them, connecting the presentation with other sources on the subject.

Means of long-distance communication include, mainly, lexical and phraseological means: with regard to - що стосується; the latter - останній. Descriptive constructions are also widely used, where the distant connection is guessed from the context. In the text such connection is provided not verbally, but by means of symbols. Among the most widely used verbs that can provide long-distance communication are remind, recall, refer, return

Considering the protocols in terms of emotional and expressive capabilities, we can not ignore the fact that due to their specificity, they have some elements of language that occur in the style of conversational literature and perform certain functional tasks. These include qualitative adjectives of subjective-evaluative meaning: vast, great, extreme, large; adverbs that neutralize the load of adjectives: very great; qualitative adverbs extremely, greatly, immensely.

Conversational colour is also obtained by the protocols of international organizations through the use of some verbs with colloquial pronouns: to face ир - зіткнутися, to bring about - здійснити. The penetration of the oral-colloquial element in the style of official-business presentation is confirmed by the use of: 1) colloquial expressions and phrases: simply - npocmo; 2) colloquial phraseology: to be in hands - знаходитися в руках; 3) emphatic structures; 4) interrogative sentences; 5) syntactic structure of a simple sentence [5, p. 61].

Protocols, as a separate type of documents, are determined by the oral type of communication. Therefore, they contain simple sentences as an element of oral speech. The use of a simple sentence against the background of large syntactic constructions introduces an element of contrast, as a result the structure of a simple sentence becomes stylistically marked.

Among the most common expressions of the euphemistic stratum are such as to be questionable-викликатисумнів;quite-достатньо; constructions with adverbs: hardly - навряд чи; sufficiently - достатньо.

Other ways of expressing negation, the so-called periphrastic ones, without expressing certain compounds or words, also converge with euphemistic ones.

Thus, the text of official-business nature has many segments that function as a whole and are 
reproduced as such. The syntactic and semantic structure of sentences in documents is very complex, it is dominated by complex syntactic units and verb forms. All this forces the translator to look for such a transformation that would correctly convey not only the grammatical content of the document, but also its pragmatic load.

In the process of describing the grammatical difficulties of English-language international treaties translating, the priority is to identify the key factors that determine them. First of all, the affiliation of the original text to a special functional style affects the nature of the translation process; international treaties are characterized by a high degree of standardization and regulation, which may require the translator to use special methods and techniques. It is well known that every word, every grammatical form, every syntactic construction of international treaties carries its own semantic load. And if the translator fails to transmit it, the adequacy and accuracy of the translation will be violated, which in turn will lead to a violation of the formalities and stereotypes of such documentation, and in the end - such a document will have no legal force, because together with the wrong translation violates the norms of international law.

Secondly, lexical, grammatical, stylistic and syntactic difficulties in translating of international treaties are created by differences in the pictures of the world of English-speaking and Ukrainianspeaking linguistic cultures. First of all, fragments of professional/branch knowledge, for example, international law, in verbal pictures of the world are verbalized by special units - terms that reveal national and cultural specifics, which also complicates the adequate choice of equivalent terms in translation. In addition, each linguistic culture has a national communicative style, and the translator must take into account the national and cultural specifics of the construction of discourse/communication.

Finally, the specifics of the construction of the original language and the language of translation, the rules of their use are also a source of difficulties in finding equivalent forms of transmission of the content of international treaties. As for the grammatical level, English and Ukrainian languages have their own morphological and syntactic norms, valid only for these languages. In the process of transmitting an opinion in another language, it is necessary to find such means and, first of all, such grammatical forms that would correspond to the content as well as merge with it as the original form merges with its content, especially when it comes to documentation of international relations. Thus, when choosing grammatical variants in the translation process, it is important to take into account the main lines of divergence of the grammatical structure of English and Ukrainian languages. After all, an important feature of the English grammatical structure is the existence of various morphological forms and syntactic constructions, the adequate translation of which usually causes difficulties.

Thus, the task of the translator of official documents is to find in the language of translation equivalent text structures and use them as standard substitutes, filling in the links in accordance with the content of the document. On the one hand, the translation of syntactic units and complexes in the documents of international diplomacy in general should not cause much difficulty, as it requires only a clear and precise adherence to the original structures with a minimum number of transformations, as illustrated in the following example: "Neither the nationality of the parties nor the civil or commercial character of the parties of the contract is to be taken into consideration..." - "Hi національна належність сторін, ні їх цивільний чи торговельний статус, ні иивільний чи торговельний характер договору не беруться до уваги...”.

However, to achieve the highest degree of adequacy, such transformations are essential, because, as noted above, the grammatical and syntactic structure of English and Ukrainian has a number of differences caused by some reasons, including the fact that English belongs to the analytical group of languages and Ukrainian - to synthetic one. In this regard, the translator is assisted by a variety of translation techniques and transformations.

The infinitive causes significant difficulties in translating English international treaties into Ukrainian. We systematize the ways of equivalent transmission of this part of speech, described in the literature: the infinitive becomes a circumstance of purpose, for example: after the adjectives "the last", "the only" and ordinal numbers the infinitive becomes the predicate of the subordinate clause; the construction "if + noun + be + infinitive" is translated by the inversion "для того щиоб»; a complex object with an infinitive turns into a contracted additional sentence; a complex subject with a passive infinitive is translated as a complex sentence with a subjunctive additional [12, p. 95, p. 185]. For example: “... the only way for us to reach ..." “... єдиний спосіб, у який ми досягнемо ...”.

It should be noted that in our investigated material in Ukrainian translations of English-language 
international treaties there are common cases when the infinitive is preserved in the translation, for example: “...the obligation of States under the Charter of the United Nations to promote universal respect for” - “... за статутом Організації Об'єднаних Начій держави зобов'язані заохочувати загальне поважання" "The State Parties to the present Treaty undertake to guarantee" - Держави, які беруть участь у иъьму договорі, зобов'язуються гарантувати".

A significant part of the total number of infinitives in the corpus of examples selected by us is nominalized when translated in accordance with the norms of the Ukrainian language, for example: “... will take appropriate steps to safeguard this right" “... зроблять належні кроки до забезпечення цього права»; “... to ensure this right” - “... для забезпечення здійснення цього права»; "the right to strike" - "право на страйки”. Not only the active, but also the passive infinitive is nominated: "Equal opportunity for everyone to be promoted in his employment" - "однакову для всіх можливість просування роботі".

The infinitive can also be nominalized in chains of enumeration, for example: "to be presumed innocent" - "презумпиію невинності", "to be informed promptly" - "негайне інформування", "not to be compelled to give testimony or to confess guilt" - "свобода від примусу щодо даваних свідчень чи визнання вини", "to have the free assistance of an interpreter" - "безоплатна допомога перекладача".

The following example uses not only the nominalization transformation, but also a repetition that does not appear in the original text, for example: "The State Parties recognize the right of everyone: a) to take part in cultural life; b) to enjoy the benefits of scientific progress and its applications; c) to benefit from the protection of the moral and material interests..." - "Держави визнають право кожної людини на: а) участь у культурному житті; б) користуваннярезультатаминаукового прогресу та їх практичне застосування; в) користування захистом моральних і матеріальних інтересів ...»

Thus, parallel infinitive constructions in the original are not always preserved in translation, becoming constructions with a noun, but the parallelism is preserved.

No less interesting for the study is the translation of adjectives and adverbs. According to the scientific research of G. Miram, adjectives are translated as subordinate definite, additional or circumstantial, or as a separate sentence [13, p. 188]. For example:
"Recognizing that the child, for the full and harmonious development of his or her personality, should grow up in a family environment, in an atmosphere of happiness, love and understanding”- "Визнаючи, що дитині для повного і гармонійного розвитку ї̈ особи необхідно зростати в сімейному оточенні, атмосфері щастя, любові йрозуміння". In this case, the definite-personal sentence in the text of original is transformed into the indefinite in the language of translation, when the subject is transformed into an object, and the adjective is transformed into an adverb.

Let's compare the following example of translation transformation: "Considering the obligation of States under the Charter of the United Nations to promote universal respect for and observance of human rights and freedoms" - "Беручи до уваги, щзо за Статутом Організачії Об'єднаних Націй держави зобов'язані заохочувати загальне поважання й додержання прав і свобод людини".

In this case, there was a division and permutation, the adjective became an adverb, and there was a subordinate clause.

Thus, as evidenced by the observation material, parallel grammatical constructions, expressed adverbs in the preambles of international documents, are always translated by parallel adverbial inversions: "considering, bearing in mind, recognizing, calling, convinced, taking due account, being of the opinion" - "уважаючи, беручи до уваги, визнаючи, нагадуючи, упевнені в тому, ураховуючи, уважскючи". In addition, the translation of the statement after the adverb is parted.

Peculiarities of the translation of adjectives, as noted by G. Miram, are represented by the fact, that this adjective, as a rule, is translated by a circumstantial sentence [13, p. 188], for example: "If adopted, it will help ...". - "Якщо такий документ буде прийнято, ие допоможе ...”; “A breach of contract committed by one of the parties is fundamental if ..." - "Порушення договору, допущене однієюзі сторін, є істотним, якщо ...”.

If in the text of the original there is an inversion, it generally remains in the text of the translation [13, p. 191]. For example: "For the purpose of the results achieved by State Parties ... there should be adopted a special document". - "Для розгляду результатів, досягнутих державами-учасницями ... приймається спеціальний документ".

The translation of attributive groups is difficult because they are very common in English and not typical of Ukrainian. As noted by philologist V. Komissarov, mostly attributive groups are 
explicated, the translator replaces the attributive group with a number of other structures in which hidden connections are revealed [8, p. 89], for example: advanced vocational training - професійна підготовка підвищеного рівня; arrangements for the custody - умови утримання під вартою; environmental and industrial hygienе - санітарний стан навколишнього середовища й гігієна прачџ в промисловості.

Complex noun predicate belongs to the phenomena common in English-language international treaties. Our observations confirm the conclusion of the scientist N. Fedorova that this type of predicate in the original text often turns into a verb predicate in the translated text [16, p. 65], for example: "A late acceptance is nevertheless effective as an acceptance if without delay the offeror orally so informs the offeree or dispatches a notice to that effect" - "Запізнілий акиепт, однак, зберігає свою чинність акцепту, якщьо оферент без затримки повідомить про ие адресата оферти усно чи надішле йому відповідне повідомлення".

When translating homogeneous members of a sentence, certain difficulties may arise due to the lack of differential subjects and objects with homogeneous subjects [13, p. 91]. But here the use of basic translation techniques comes for help, which provide the necessary level of translation adequacy. For example: "State Parties shall ensure that the institutions, services and facilities responsible for the care or protection of children shall conform with the standards established by competent authorities, particularly in the areas of safety, health, in the number and suitability of their stuff, as well as competent supervision” - "Держави учасниці забезпечують те, щуоб установи, служби й органи, відповідальні за піклування про дітей або їх захист, відповідали нормам, установленим компетентними органами, зокрема, в галузі безпеки й охорони здоров'я та з точки зору чисельності й придатності їх персоналу, а також компетентного нагляду”.

Conclusions. Thus, the analysis of special sources on the translation of international treaties has identified a number of factors that cause translation difficulties: a high degree of standardization of official business style and diplomatic background, differences in professional and sectoral pictures of the world and national-cultural specifics of terminological means of their verbalization. national communicative style and typological differences in lexical and grammatical means of the original language and lnguage of translation, norms of their use. As a result of comparative study of grammatical elements and structures in the original English texts of international treaties and their Ukrainian translations: infinitives, adjectives and adverbs, attributive constructions, homogeneous sentence members, typical translation transformations are identified, the application of which contributes to equivalence and adequacy.

\section{References:}

1. Бігун В. Мовно-правничі аспекти зовнішньоекономічних договорів (контрактів). Юстініан. 2004. № 2. C. $6-9$.

2. Борисенко І. І., Свтушенко Л. І., Дайнеко В. В. Англійська мова в міжнародних документах і дипломатичній кореспонденції : навчальний посібник. 2-е видання, зі змінами та доповненнями. Київ : Логос, 1999. $416 \mathrm{c}$.

3. Закон України про зовнішньоекономічну діяльність від 16 квітня 1991 p. № 959-XII. URL: http://zakon.rada.gov.ua/cgi-bin/laws/main.cgi?nreg=995_015.

4. Зарума-Панських О. Р. Англійська лексика міжнародних договорів: структурні, семантичні та дискурсні особливості : автореф. дис. ... канд. філол. наук. Львів, 2001. 19 с.

5. Калюжная В. В. Стиль англоязычных документов международных организаций. Київ : Наукова думка, 2008. $120 \mathrm{c}$.

6. Кащишин Н. Є. Особливості перекладу англійських дипломатичних термінів українською мовою. Іноземна філологія. 2011. Вип. 123. С. 240-245.

7. Кизим В. Ю. Стилістичні особливості перекладу міжнародних документів (на матеріалі законодавчої бази щодо захисту прав людини та протидії торгівлі людьми). Фаховий та художній переклад: теорія, методологія, практика : матер. допов. III Міжнар. наук.-практ. конф. 2-3 квітня 2010 р. / за заг. ред. А. Г. Гудманяна, С. І. Сидоренка. Київ : Аграр Медіа Груп, 2010. С. 208-214.

8. Комиссаров В. Н. Лингвистика перевода. Москва : Международные отношения, 2009. 170 с.

9. Комиссаров В. Н. Пособие по переводу с английского на русский. Москва : Высшая школа, 1965. $288 \mathrm{c}$.

10. Комиссаров В. Н. Слово о переводе. Москва : Международные отношения, 1973. 216 с.

11. Коновченко О. В. Класифікація міжнародної контрактно-договірної документації: документознавчий аспект. Вісник Харківської держаної академії культури. 2012. Вип. 37. С. 204-211. 
12. Мацько Л. І. Стилістика української мови : підручник для філологічних спеціальностей вищих навчальних закладів. Київ : Вища школа, 2003. 462 с.

13. Мирам Г. Э. Основы перевода. Киев : Эльга Ника-Центр, 2013. 280 с.

14. Мирам Г. Э. Профессия: переводчик. Киев : Ника-Центр, 2004. 160 с.

15. Положення про форму зовнішньоекономічних договорів (контрактів) : Наказ Міністерства економіки та з питань європейської інтеграції України від 06.09.2001 № 201.

16. Федорова Н. П. Перевод с английского языка. Повышенный уровень. Часть 1. Москва : Академия, 2007. $160 \mathrm{c}$.

17. Шкурупій О. В. Зовнішньоекономічна діяльність підприємства : навчальний посібник. Київ : Центр учбової літератури, 2012. $248 \mathrm{c.}$

18. Ярова Л. О. Граматичні особливості англомовних міжнародних документів в аспекті перекладу. Наукові записки. Серія “Філологічні науки”. 2016. Вип. 144. С. 233-237.

\section{Шеверун Н. В., Лейцюсь Г. М., Джурило А. П. ДІЛОВІ СТАНДАРТИ В ЛЕКСИЦІ МІЖНАРОДНИХ ДОГОВОРІВ ТА ОСОБЛИВОСТІ ЇХ ПЕРЕКЛАДУ}

Стаття присвячена дослідженню ділових стандартів у словниковому складі англомовних міжнародних договорів та основним особливостям їх перекладу украӥнською мовою. У процесі дослідження виявлено, що залежно від типу документа, завдань комунікативного характеру текстовий матеріал документа набуває тієї чи іншої форми організаиії. Цей факт стає вирішальним при виборі мовних засобів у прочесі перекладу.

Виявлено, що при перекладі договорів необхідно дотримуватися не лише семантичної сторони, а й за можливості відбирати структури, що є найбільш близькими або збігаються зі структурами в тексті оригіналу як з точки зору лексики та синтаксису, так $і$ з точки зору граматичних конструкцій.

У прочесі дослідження встановлено, щзо синтаксична й семантична структура речень договорів є дуже складною, у ній переважають складні синтаксичні одиниці та дієслівні форми. Усе че змушує перекладача шукати таку трансформацію, яка б правильно передавала не лише граматичний зміст документа, а і його прагматичне навантаження.

Аналіз спеціальних джерел щодо перекладу міжнародних договорів виявив низку факторів, що викликають труднощі в перекладі: високий ступінь стандартизащії офіиійно-ділового стилю й дипломатичного походження, відмінності в професійних і галузевих картинах світу й національно-культурні особливості термінологічних засобів їх вербалізації, стиль і типологічні відмінності в лексичних і граматичних засобах мов оригіналу та перекладу, норми їх використання.

Ключові слова: міжнародний договір, міжнародна документачія, міжнародна комунікачія, міжнародна співпрачя, граматичні трансформаиії. 